\title{
Women's Empowerment and Ideal Family Size: An Examination of DHS Empowerment Measures In Sub-Saharan Africa
}

\section{By Ushma D. Upadhyay and Deborah Karasek}

Ushma D. Upadhyay is assistant research scientist, and Deborah Karasek is research manager, both with Bixby Center for Global Reproductive Health, University of California, San Francisco, USA.

\begin{abstract}
CONTEXT: The Demographic and Health Survey (DHS) program collects data on women's empowerment, but little is known about how these measures perform in Sub-Saharan African countries. It is important to understand whether women's empowerment is associated with their ideal number of children and ability to limit fertility to that ideal number in the Sub-Saharan African context.
\end{abstract}

METHODS: The analysis used couples data from DHS surveys in four Sub-Saharan African countries: Guinea, Mali, Namibia and Zambia. Women's empowerment was measured by participation in household decision making, attitudes toward wife beating and attitudes toward refusing sex with one's husband. Multivariable linear regression was used to model women's ideal number of children, and multivariable logistic regression was used to model women's odds of having more children than their ideal.

RESULTS: In Guinea and Zambia, negative attitudes toward wife beating were associated with having a smaller ideal number of children (beta coefficients, -0.5 and -0.3, respectively). Greater household decision making was associated with a smaller ideal number of children only in Guinea (beta coefficient, -0.3 ). Additionally, household decision making and positive attitudes toward women's right to refuse sex were associated with elevated odds of having more children than desired in Namibia and Zambia, respectively (odds ratios, 2.3 and 1.4); negative attitudes toward wife beating were associated with reduced odds of the outcome in Mali (0.4).

CONCLUSIONS: Women's empowerment-as assessed using currently available measures-is not consistently associated with a desire for smaller families or the ability to achieve desired fertility in these Sub-Saharan African countries. Further research is needed to determine what measures are most applicable for these contexts. International Perspectives on Sexual and Reproductive Health, 2012, 38(2):78-89, doi: 10.1363/3807812

The literature on women's empowerment has defined and conceptualized "empowerment" using different and often interchangeable terms, including "autonomy," "status" and "agency." 1,2 According to one definition, empowerment is "the expansion of people's ability to make strategic life choices in a context where this ability was previously denied to them." ${ }^{3}$ Two central components of empowerment are the agency and the resources needed to exercise life choices. ${ }^{2,3}$ In addition, the construct of women's empowerment encompasses many dimensions, including reproductive, economic, social and cultural, familial and interpersonal, legal, political and psychological, ${ }^{2}$ which leads to wide variation in conceptualization.

Given this wide variation, women's empowerment is difficult to measure consistently. Studies often assess women's autonomy with an index measuring participation in decision making about various household issues, which represents women's degree of control over their environment. Some researchers include both major decisions (e.g., large household purchases) and minor decisions (e.g., what food to cook) in the index, ${ }^{4}$ whereas others exclude day-to-day household choices and those that are traditionally within the woman's domain. ${ }^{5}$ Other measures of women's empowerment assess freedom of movement, ${ }^{6,7}$ differ- ences in age and education between marital partners, 8,9 and the process of spouse selection. ${ }^{10}$

Even with a clear definition and conceptualization, these constructs are difficult to quantify in a standardized way within a given population. To measure empowerment at an individual level, researchers must translate the amorphous construct into a set of specific questions that population-based surveys can ask; ideally, those questions would be applicable to individual respondents with a diverse set of social and demographic characteristics. For example, young women who have not had sex would not have the experience needed to answer questions about sexual power. In such a case, hypothetical situations could be used to ascertain attitudes and beliefs, but such situations are often difficult for people to fully understand and respond to realistically. ${ }^{11}$

Another challenge is the variation in cultural contexts that affect the measurement of women's empowerment. A measure that captures empowerment in one context may have limited relevance in another, as is the case with measures of mobility in communities where free movement is the norm for women. Thus, for the validity of cross-national comparisons, it is important to identify universally applicable measures, regardless of the gender equity environment. 
To meet this challenge, the DHS program began incorporating measures of women's empowerment in the late 1990s. Although some of these items were originally conceptualized and developed for the Asian context, and for South Asian countries in particular, ${ }^{12,13}$ they have been included in the DHS standard questionnaire, providing standardized measures of women's empowerment in a wide variety of countries. ${ }^{14}$ These include items on household decision making and women's acceptance of gender inequity within relationships. Specifically, one set of questions asks about the reasons that justify a husband's beating his wife, and another the reasons that justify a wife's refusing to have sex with her husband. ${ }^{15}$ Questions on such gender-role attitudes measure the extent of women's acceptance of men's control over women, ${ }^{9}$ and are associated with the extent of women's power over household decision making. ${ }^{16-18}$

The DHS empowerment data have led to valuable theoretical and empirical contributions to the literature on women's empowerment and various health outcomes around the world. ${ }^{19-22}$ Recently, however, researchers have challenged the validity of DHS empowerment measures in Sub-Saharan Africa, voicing a need to improve the measures' conceptual basis and contextual grounding. ${ }^{23-25}$ Women's empowerment may take on different meanings in Africa, where polygamy, ${ }^{26,27}$ HIV prevalence, ${ }^{28}$ ideal family size $e^{29}$ and the social importance of fertility ${ }^{30-32}$ are known to be greater than in the Asian context. Further exploration is needed to determine whether dimensions of empowerment conceptualized for other cultural contexts are relevant in Sub-Saharan Africa.

\section{Empowerment and Ideal Family Size}

A broad body of research demonstrates that women's empowerment is associated with reproductive outcomes, including contraceptive use, ${ }^{33-36}$ fertility $^{14,37,38}$ and birth intervals. ${ }^{39}$ Some researchers suggest that empowerment is a key pathway through which education influences fertility. ${ }^{13,40}$ Few studies on women's empowerment and reproductive outcomes, however, have been conducted in Sub-Saharan African countries. Our review of the literature identified only 17 quantitative analyses conducted in Sub-Saharan Africa. Of these, only one examined empowerment and ideal family size, ${ }^{36}$ and two others examined empowerment and partner communication about ideal family size, ${ }^{38,41}$ all three used DHS data, and two used the household decision-making index as a measure of women's empowerment. ${ }^{36,38}$

One of the studies used the 2002 Eritrea DHS to examine whether women's autonomy is associated with reproductive preferences. ${ }^{36}$ Women's final say in decisions regarding day-to-day household purchases was associated with having a small ideal family size, wanting no more children and ever-use of modern contraceptives. The results suggest that social and demographic factors such as employment and economic status affect women's reproductive preferences not only directly, but also indirectly, by increasing women's autonomy, which in turn influences reproductive preferences.

Another study, based on the 1994 Zimbabwe DHS, found that women's increased household decision making was associated with lower fertility and having discussed ideal family size with their partners. ${ }^{38}$ It demonstrated that the addition of decision-making variables provided independent explanatory power beyond that of traditional measures of women's status, such as educational attainment and labor force participation.

According to the third study, which used data from the 1990 Ethiopia DHS, women's autonomy-as measured by literacy-was associated with an increased likelihood of spousal communication about ideal family size. ${ }^{41}$ On the basis of these studies, we would expect women's empowerment to be associated with a smaller ideal number of children in other African countries.

Exploring the relationship between women's empowerment and ideal fertility in diverse Sub-Saharan African countries with comparable measures will help fill the current gap in the literature. It is imperative that we understand this relationship in Sub-Saharan Africa, where the fertility transition has slowed or stalled in recent years. ${ }^{42}$ Fertility rates in Sub-Saharan Africa are the highest in the world; women average five to six births in their lifetime. ${ }^{43}$ Yet, many African women desire smaller families even though they are not practicing contraception. In one study based on DHS data from 29 Sub-Saharan African countries, 24\% of married women aged 15-49 did not want a child soon or at all, but reported not using any contraceptive method. ${ }^{44}$ The average total fertility rate (TFR)-the number of births per woman at current agespecific rates-would decline considerably in Sub-Saharan Africa if women there had only the number of births they wanted. ${ }^{29}$ Such statistics led us to ask "Would improving women's empowerment help them have just the number of children they want and eventually reduce fertility rates in the region?"

This study aims to answer that question by exploring whether women's empowerment-as assessed by DHS measures-is associated with their ideal number of children and the achievement of their desired fertility in four Sub-Saharan African countries. We also examine how husbands' fertility desires influence the relationship between women's empowerment and their ideal number of children. There is wide consensus that men strongly influence couples' childbearing behavior. ${ }^{45-47}$ Although African men's ideal number of children tends to be higher than women's, ${ }^{29,48,49}$ one study in Ghana suggests that husbands' declining fertility desires are largely responsible for national-level reductions in fertility. ${ }^{50}$

\section{Country Setting}

Guinea, Mali, Namibia and Zambia have important social and demographic differences and similarities that make them interesting to study in the context of empowerment and fertility desires. In general, Mali has some of the worst 
social and economic indicators in the region, and Namibia has some of the best; Guinea's and Zambia's fall in between. On the basis of gender-related economic, political and educational indicators, Mali and Guinea have relatively less gender equity than Namibia and Zambia. ${ }^{51,52}$

Age at first marriage-an important indicator of lifetime fertility and gender opportunities-varies across countries, with women in Guinea having the lowest median age at marriage (16.0), followed by Mali (16.6), Zambia (19.2) and Namibia (28.2). ${ }^{53-56}$ Few youth complete primary school in Mali (19\% of females and 36\% of males), and even fewer do so in Guinea (7\% and 18\%). ${ }^{53,54}$ Educational attainment is higher in Zambia (54\% of females and $69 \%$ of males complete primary school), ${ }^{55}$ and in Namibia, females actually have higher rates of primary education than males ( $76 \%$ and $69 \%$, respectively). ${ }^{56}$

Several other factors speak to the gender environments of the countries. In Mali, 90\% of women aged 15-49 have undergone female circumcision, and $45 \%$ of married women are in a polygamous union. ${ }^{54}$ Similarly, in Guinea 96\% of women report being circumcised. ${ }^{55}$ Of note, whereas prevalence rates of HIV among adults are low in Mali and Guinea (1\%), they are significantly higher in Zambia and Namibia (13-14\%). ${ }^{57}$

Mali, Guinea and Zambia have higher overall fertility than Namibia. Mali has a persistently high TFR of 6.6-one of the highest in the region, ${ }^{53}$ Guinea's TFR is $5.7 .^{54}$ Fertility rates in Zambia have decreased slowly, by one birth over the past three decades, to 6.2 in $2007 .{ }^{55}$ Fertility in Namibia has decreased substantially, from 5.4 in 1992 to 3.6 in $2007 .^{56}$

Contraceptive knowledge is at least $85 \%$ in all four countries; ${ }^{53-56}$ however, modern method use is considerably lower among women in Mali and Guinea (7\% and $6 \%$, respectively) than in Zambia and Namibia (33\% and $53 \%$ ). These contraceptive prevalence rates speak to the religious environment of the countries (Namibia and Zambia are primarily Christian, whereas Guinea and Mali are primarily Muslim), as well as their family size ideals and family planning access.

\section{Conceptual Framework}

This study posits that women's empowerment influences their ideal number of children and their ability to limit fertility to that ideal number. Our conceptual framework implies a pathway in which greater empowerment comes with greater agency and resources, which stimulate a woman's desire for expanded life opportunities and drive down her ideal number of children. This rests on the assumption that a more empowered woman will desire roles in addition to motherhood and greater opportunities for herself and for her children. By limiting her number of children, she will have more resources to spend on herself and her family. A smaller ideal number of children, therefore, seems to be a plausible outcome of women's empowerment. A woman's ideal number of children is also likely affected by her social and demographic characteristics, such as age and wealth, and by her husband's ideal number of children.

Increased agency and resources, which result from empowerment, can help a woman control her environment to achieve her now reduced ideal number of children. The lower the stated ideal number of children, the more likely she will have more children than she wants-particularly in a high-fertility context. Neither women's use of contraceptives nor the availability of contraceptive services are examined or controlled for in the study because they are on the causal pathway between empowerment and achievement of ideal fertility and therefore, controlling for them would conceal any effects of empowerment.

Thus, we hypothesize that more empowered women will have a smaller ideal family size than less empowered women because having fewer children will allow them greater freedom to pursue life opportunities. We also hypothesize that more empowered women will be more likely than less empowered women to limit fertility to their desired number of children because they have the agency and resources to take the actions needed to achieve their desired fertility. Given the contextual differences in these countries, we expect that the associations of reproductive outcomes with women's empowerment may be greater where fertility rates are high and the gender norms are least equitable, such as Mali, than where fertility rates are low and gender equity is greater, as in Namibia.

If a link is found, it would provide support for family planning programs to address women's empowerment as part of their mission to help women and couples have only the number of children they want. Such empowerment interventions could result in greater interest in family planning services and create demand for smaller families. Substantial reductions in fertility rates could occur if women could have only the number of children they consider ideal.

\section{METHODS \\ Data Sources}

The DHS data analyzed here are from four of the most recent surveys in Sub-Saharan Africa that contain the measures required to answer our research questions: Guinea (2005), Mali (2006), Namibia (2006-2007) and Zambia (2007). ${ }^{53-56}$ The surveys collected data on behavioral, social and demographic indicators, including women's status, desired number of children and fertility. Surveys were translated into the major local languages within each country, and were approved by the institutional review board of Macro International, the local governments and implementing partners.

Because husband's fertility desires were a key issue of interest, we focused on matched couples. Use of the DHS couples file limited the sample to currently married women aged 15-49 whose husband was physically present, living in the same household and aged 15-59 (except in Namibia, where men were aged 15-49). We excluded anyone for whom data were unavailable for at least one of the em- 
powerment measures (one woman in Guinea, zero in Mali, five in Namibia and seven in Zambia), which resulted in a final weighted sample of 1,993 matched couples in Guinea, 2,668 in Mali, 844 in Namibia and 3,197 in Zambia.

We compared social and demographic characteristics and empowerment indicators among all women in the individual file and in the subsample of women in the couples file and found few significant differences between the two files for each country (not shown). In all countries except Namibia, the sample of individual women was slightly older and wealthier than the couples subsample. Empowerment indicators of decision making and attitudes toward wife beating were similar across both groups. On average, compared with women in the individual sample, women in the couples subsample reported a lower number of reasons that justify refusing sex to one's husband.

\section{Dependent Variables}

-Ideal number of children. The DHS assesses ideal family size by asking women with children, "If you could go back to the time you did not have any children and could choose exactly the number of children to have in your whole life, how many would that be?" Women with no children at the time of the survey are asked, "If you could choose exactly the number of children to have in your whole life, how many would that be?" Both questions allow nonnumeric responses, such as "As god decides," which we included in our analysis because we were concerned that not doing so would bias the results. Researchers have recommended including nonnumeric responses in analyses of family size desires. ${ }^{58}$ Although previous studies have shown that those who give nonnumeric responses are likely to want more children than those who provide numeric responses, and are less likely to adopt behaviors that result in smaller families, ${ }^{59}$ a subanalysis of our data found few differences in empowerment indicators between women who provided numeric responses and those who provided nonnumeric ones (not shown). Thus, nonnumeric responses were recoded to the mean value for the rest of the country sample.

- Having more than one's ideal number of children. We created a dichotomous measure of whether a woman had had more living children than her reported desired number of children by subtracting her reported ideal number of children from her reported actual number. If the total was greater than zero, she was coded as having had more children than her stated ideal. Women who provided a nonnumeric ideal number of children were coded as not having had more children than their stated ideal. Because young women in the midst of their reproductive years are unlikely to have completed childbearing, this outcome was assessed only among women aged 35 or older.

\section{Independent Variables}

Our key explanatory variables were the three women's empowerment indicators from the standard DHS questionnaire: women's role in household decision making, at- titudes toward wife beating and attitudes toward women's right to refuse sex.

-Women's role in household decision making. Each woman reported who in her family usually had the final say in decisions about her health care, major household purchases, household purchases for daily needs and visits to family or relatives. Response options included the woman alone, the woman jointly with her husband, her husband alone, the woman jointly with others and others alone. We created a dichotomous variable that divided respondents who reported having any say (alone or jointly) in all four household decisions-indicating a higher level of empowerment-and those who reported any other combination. Women missing data for one decision, but who reported having any say in the others, were categorized as having any say in all four.

-Attitudes toward wife beating. Women were asked "Sometimes a husband is annoyed or angered by things that his wife does. In your opinion, is a husband justified in hitting or beating his wife in the following situations: If she goes out without telling him? If she neglects the children? If she argues with him? If she refuses to have sex with him? If she burns the food?" We divided respondents into those who said that none of the reasons are justified-indicating a higher level of empowerment-and those who said one or more reasons are justified. Women missing data for one reason, but who reported that the other four reasons are not justified, were categorized as reporting no reasons are justified.

-Attitudes toward refusing sex. The DHS asks women, "Husbands and wives do not always agree on everything Please tell me if you think a wife is justified in refusing to have sex with her husband when: She knows her husband has a sexually transmitted disease? She knows her husband has sex with other women? She has recently given birth? She is tired or not in the mood?" We divided respondents into women who stated that all of the reasons are justified-indicating a higher level of empowermentand those who said one or more reasons are not justified. Women missing data for one reason, but who stated that the other reasons are justified, were categorized as reporting that all reasons are justified.

- Husband's influence. The analysis of empowerment and women's ideal number of children controlled for husbands' ideal number of children, which was coded as a continuous variable using the same questions described above for women; nonnumeric responses were recoded to the mean value for the rest of the country sample. Our analysis of empowerment and women's ability to have no more than their ideal number of children controlled for husbands' ideal number of children relative to wives'; wives' nonnumeric responses were entered as the mean value. We created four categories: husband agrees with his wife (including couples in which both the husband and wife gave nonnumeric responses), husband's ideal is higher than his wife's, husband's ideal is lower than his wife's and husband gave a nonnumeric response but his wife 
did not. We used this relative measure instead of the continuous variable because we were specifically interested in what happens when husbands and wives have different ideal family sizes.

- Social and demographic characteristics. Additionally, the analyses included several measures of women's social and demographic characteristics as controls: current age, education, residence, polygamous union and a household wealth index. The wealth index is precalculated and provided in the DHS data sets. * Our analysis of empowerment and ideal number of children also controlled for number of living children.

\section{Data Analyses}

We first described the characteristics of the matched couple sample, estimating means and prevalence rates of fertility desires and behavior and women's empowerment indicators. Then, we used linear regression to examine whether women's empowerment and husbands' ideal number of children are associated with women's ideal number of children after controlling for social and demographic characteristics. To assess the independent contribution of the three empowerment indicators, we included each indicator alone in a model with husbands' ideal number of children and social and demographic variables (not shown); however, beta coefficients were similar to those found in a model that included all three indicators, so we present only the combined model.

Finally, to examine the association between empowerment and achievement of ideal family size, we used multivariable logistic regression to model the probability of having had more children than desired among women 35 or older. Limiting the sample to older women allowed us to isolate those who had probably completed their childbearing. The sample sizes for this analysis were 724 in Guinea, 805 in Mali, 303 in Namibia and 945 in Zambia. This model incorporated all of the variables used in the previous analyses as independent variables: the three women's empowerment indicators, husbands' ideal number of children (relative to their wives'), and social and demographic variables. Although a woman's ideal number of children is causally related to whether she can achieve that ideal, we did not include it in the model because of potential endogeneity, given that ideal number of children was used to calculate the outcome, and it is on the causal pathway.

All analyses were performed using STATA 12. We used STATA's svy commands to account for the complex survey design of the DHS by incorporating women's sampling weights and adjusting the standard errors for the cluster sampling of primary sampling units. Thus, population-

\footnotetext{
*The DHS collects data on a variety of household assets. Each household asset for which information is collected is assigned a weight or factor score generated through principal components analysis. The resulting asset scores are standardized in relation to a standard normal distribution with a mean of zero and a standard deviation of one. These standardized scores are then used to create the break points that define wealth quintiles (source: Measure DHS, 2011 Wealth Index, Calverton, MD USA: Measure DHS, <http://www.measuredhs.com/topics/Wealth-Index. cfm>, accessed May 15, 2012).
}

based estimates account for the differential probability of selection into the survey.

\section{RESULTS \\ Descriptive Findings}

The majority of women in Guinea, Mali and Zambia lived in rural areas (67-78\%; Table 1); in Namibia, the majority lived in urban areas (57\%). Compared with the other three countries, Namibia had higher proportions of women in the richest quintile (30\% vs. 15-18) and of women who had at least a secondary education (63\% vs. 5-25\%). Polygamy was common in Mali and Guinea (42\% and 51\%, respectively), but less so in Namibia and Zambia (15 and $11 \%$ ). Only 14\% of women in Namibia had at least five living children-about half the proportion found in the other countries (25-30\%).

Women's mean ideal number of children was lowest in Namibia (3.4) and highest in Mali (6.6). In each country, the mean ideal number of children among husbands was at least one child higher than among wives, ranging from 4.7 in Mali to 9.9 in Guinea. The proportion of women 35 or older who reported having had more children than their ideal was greatest in Zambia (28\%), followed by Namibia (26\%), Guinea (15\%) and Mali (12\%).

Substantial variability was found among the four countries in the women's empowerment indicators. Women in Namibia were more empowered than those in the other three countries, as the country had the greatest proportions of women who reported that they have any say in all four household decisions (68\%), that none of the five reasons for wife beating are justified (69\%) and that all three reasons for refusing sex are justified (75\%). Mali had the smallest proportions of women who reported that they have any say in all four household decisions (11\%) and that all three reasons for refusing sex are justified (10\%); Guinea had the smallest proportion of women who reported that none of the five reasons for wife beating are justified (12\%)

\section{Empowerment and Ideal Number of Children}

Results of the linear regression model of women's ideal number of children differed by country, but showed some overall trends (Table 2, page 84). In general, each of the three measures of women's empowerment declined as the ideal number of children rose; however, most coefficients did not reach statistical significance.

Of the empowerment measures, not condoning wife beating was the one most consistently linked to a smaller ideal number of children. Women's reporting that none of five proposed justifications for wife beating are acceptable was associated with a smaller ideal family size in Guinea and Zambia (adjusted beta coefficients, -0.52 and -0.25 , respectively); in Namibia, the association was negative in the unadjusted model $(-0.60)$, but not after adjusting for other variables, specifically wealth and education. In Mali, reporting that none of the five reasons justify wife beating was associated with a larger ideal family size (0.49). 
In regard to the other empowerment measures, household decision making and stating that all three reasons for refusing sex are justified were associated with ideal number of children only in Guinea (adjusted beta coefficients, -0.25 and -0.33 , respectively). In addition, the husband's ideal number of children was positively associated with the wife's ideal number of children in all countries but Mali (0.04-0.08)

Of the social and demographic variables, wealth quintile and education level were generally negatively associated with the ideal number of children; whereas number of living children and age (in Namibia and Zambia only) were positively associated with the outcome.

\section{Empowerment and Having More Children than Ideal}

The results of the logistic regression models examining the odds of having more children than desired among the subsample of married women aged 35 or older show that few of the empowerment indicators were associated with achievement of ideal fertility (Table 3, page 85). In Namibia, women who reported having a say in all types of household decisions were significantly more likely than other women to have had more children than their ideal (odds ratio, 2.3). Similarly, in Zambia, believing that a wife can refuse her husband sex for any reason was associated with elevated odds of having had more children than ideal (1.4). Only in Mali was there an empowerment measure negatively associated with having more children than ideal: Women who reported that no reasons justify wife beating were less likely than others to have had more children than they desired (0.4).

In all four countries, being in a couple in which the husband's ideal number of children was higher than the wife's was associated with greater odds-nearly 12 times as great in Mali-of having had more children than ideal (odds ratios, 2.2-11.9). In two countries, Guinea and Mali, the risk also increased when a woman's husband gave a nonnumeric response (3.2 and 9.1, respectively). In Guinea and Zambia, women's odds of having more children than ideal increased slightly with increasing age (1.1 each). Education was significant only in Mali, where having a secondary education was associated with greater odds of having more children than desired (2.9); wealth was not significant in any of the multivariable logistic regression models.

\section{DISCUSSION}

According to our results, women's empowerment-as assessed by DHS measures-is generally associated with a desire for fewer children in four Sub-Saharan African coun-

†Nonnumeric responses are entered as the mean ideal number of children. FFinal say alone or jointly with husband in regard to one's own health care, making major household purchases, making household purchases for daily needs and visiting family or relatives. $\$$ Whether a husband is justified in beating his wife if she goes out without telling him, neglects the children, argues with him, refuses to have sex with him or burns the food. +tWhether a woman is justified in refusing sexual intercourse with her husband if he has a STI, he has sex with other women, or she is tired or not in the mood. Notes: All data are percentages, unless otherwise noted.

Percentage distributions may not add to 100.0 because of rounding.

TABLE 1. Selected measures among women in matched couples in four Sub-Saharan African countries, Demographic and Health Surveys, 2005-2007

$\begin{array}{lllll}\text { Measure } & \text { Guinea, } & \text { Mali, } & \text { Namibia, } & \text { Zambia, } \\ & 2005 & 2006 & 2006-2007 & 2007 \\ & (\mathrm{~N}=1,993) & (\mathrm{N}=2,668) & (\mathrm{N}=844) & (\mathrm{N}=3,197)\end{array}$

\section{SOCIAL AND DEMOGRAPHIC}

Age

$\begin{array}{rrr}30.5 & 17.9 & 27.5 \\ 39.3 & 46.4 & 43.0 \\ 30.2 & 35.7 & 29.5 \\ 73.8 & 43.2 & 66.9 \\ 26.2 & 56.8 & 33.1 \\ & & \\ 21.3 & 14.6 & 24.3 \\ 21.0 & 11.8 & 18.8 \\ 19.1 & 19.0 & 19.5 \\ 21.3 & 24.7 & 19.7 \\ 17.3 & 29.8 & 17.7 \\ & & \\ 84.9 & 12.1 & 12.8 \\ 10.5 & 25.2 & 62.2 \\ 4.6 & 62.7 & 25.0 \\ & & \\ 58.2 & 85.0 & 88.6 \\ 41.8 & 15.0 & 11.4 \\ & & \\ 10.0 & 8.4 & 7.5 \\ 31.9 & 46.0 & 32.3 \\ 27.8 & 31.2 & 31.6 \\ 30.3 & 14.3 & 28.7\end{array}$

$15-24$

$25-34$

35-49

Residence

Rural

Urban

Household wealth index

Poorest

Poor

Middle

Rich

Richest

Education

None

Primary

$\geq$ secondary

Polygamous union

No

Yes

No. of living children

0

$1-2$

3-4

$\geq 5$

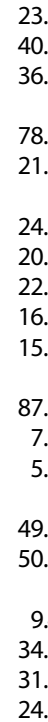

FERTILITY DESIRES AND BEHAVIOR

Women

Mean ideal no. of childrent

Ideal no. of children

$0-2$

$3-5$

$\geq 6$

Nonnumeric response

Had more children than ideal

All women

Aged $\geq 35$

23.5

783

21.7

24.7

20.8

22.7

16.5

15.3

87.8

7.0

5.2

49.3

50.7

9.4

34.7

24.9

30.3

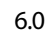

6.6

1.8

29.8

50.1

18.3

6.2

12.0

Husbands

Mean ideal no. of childrent

Ideal no. of children

$0-2$

3-5

$\geq 6$

Nonnumeric response

Ideal no. of children relative to wife's

Agrees

Higher

Lower

Gave nonnumeric response,

but wife did not

WOMEN'S EMPOWERMENT

Decision making¥

Has any say in all four

household decisions

Mean no. of household decisions in

33.7

which woman has any say (range, 0-4)

2.0

Attitudes toward wife beating $\S$

None of the five reasons are justified $\quad 11.8$

Mean no. of justified reasons (range, $0-5$ ) 3.2

Attitudes toward refusing sex with husbandt†

All three reasons are justified

29.3

Mean no. of justified reasons (range,0-3) 1.7

Notes at left.
27.5

33.1

4.3

18.8

9.7

17.7

2.2

7.5

31.6

28.7

5.1

6.7

53.0

33.6

6.8

12.1

27.8

5.7

7.5

46.4

41.9 


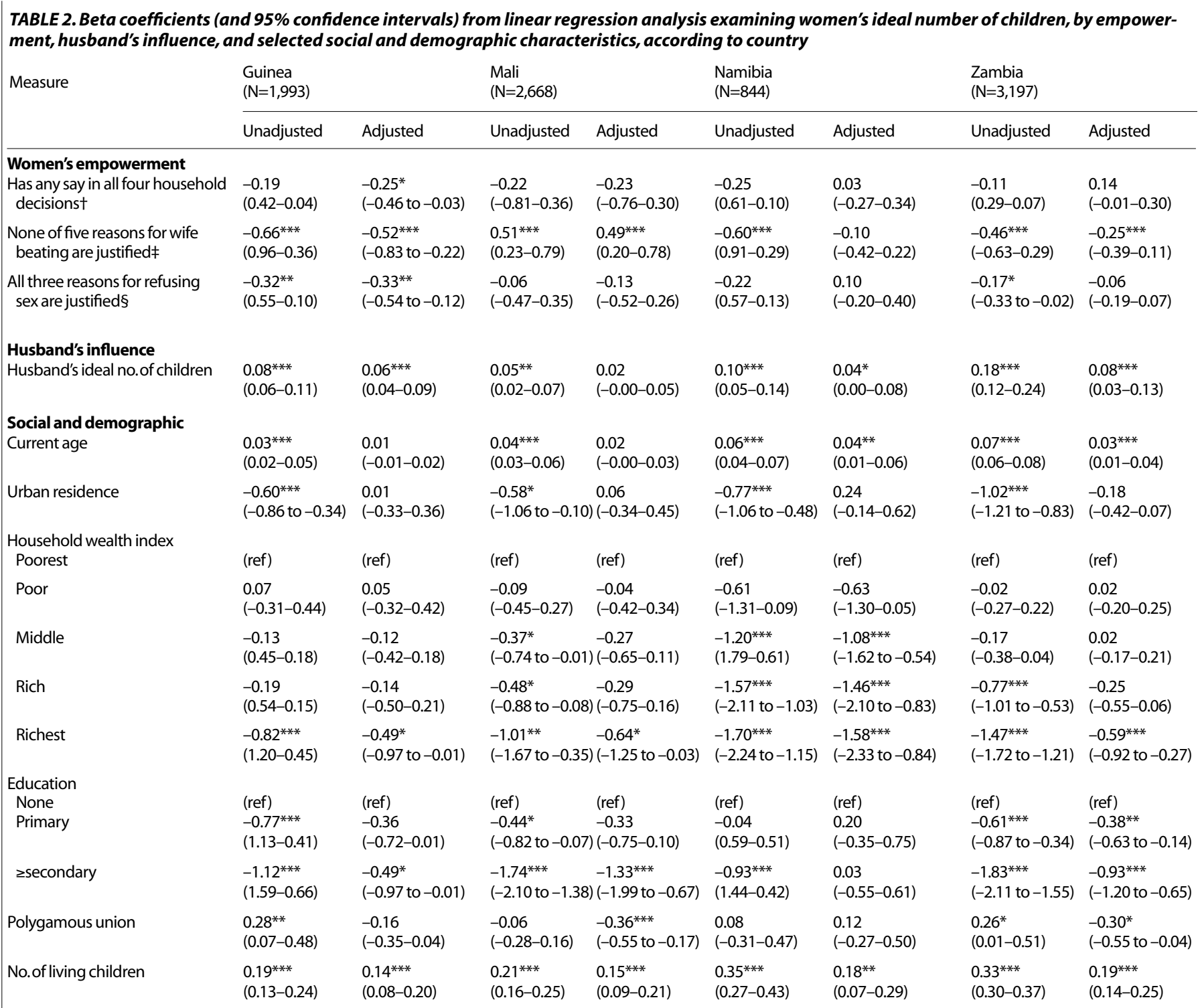

${ }^{*} \mathrm{p}<.05 .{ }^{* *} \mathrm{p}<.01 .{ }^{* * *} \mathrm{p}<.001$. FFinal say alone or jointly with husband in regard to one's own health care, making major household purchases, making household purchases for daily needs and visiting family or relatives. $¥$ Whether a husband is justified in beating his wife if she goes out without telling him, neglects the children, argues with him, refuses to have sex with him or burns the food. §Whether a woman is justified in refusing sexual intercourse with her husband if he has a STI, he has sex with other women, or she is tired or not in the mood.

tries, although this finding was not universal or consistent. In Guinea, greater household decision making was associated with a smaller ideal number of children, and in Guinea and Zambia, women's egalitarian gender-role attitudes were associated with a smaller ideal number of children. Surprisingly, in Mali, women's egalitarian gender-role attitudes toward wife beating were associated with a larger ideal number of children.

The results from analyses of the association between women's empowerment and achievement of desired family size were also mixed. In Mali, negative attitudes toward wife beating were associated with women's ability to achieve desired family size; in Namibia and Zambia, having a say in household decision making and stating that refusing to have sex with one's husband is justified for any reason, respectively, were associated with having more children than desired.
We had expected that women with greater decisionmaking power and equitable gender-role attitudes would have the agency and resources to realize their intentions. It may be that more empowered women fulfilled social expectations of high fertility, although they personally desired smaller families. Alternatively, the findings could reflect a flaw in the measures of empowerment. Some researchers have noted that when women have the primary or sole decision-making authority, it is a marker for an absent, nonparticipating partner, ${ }^{60,61}$ in such cases, sole decision making does not reflect empowerment, because the woman carries the entire burden of household responsibilities.

We observed weak associations between attitudes toward refusing sex and both study outcomes. Among the eight multivariable models, this empowerment indicator was significant in the expected direction in only one. This result may indicate that women who believe in a woman's 
TABLE 3. Adjusted odds ratios (and 95\% confidence intervals) from multivariable logistic regression assessing the likelihood among married women aged 35 or older of having more than their ideal number of children, by empowerment, husband's influence, and selected social and demographic characteristics, according to country

\begin{tabular}{|c|c|c|c|c|}
\hline Measure & $\begin{array}{l}\text { Guinea } \\
(\mathrm{N}=724)\end{array}$ & $\begin{array}{l}\text { Mali } \\
(\mathrm{N}=805)\end{array}$ & $\begin{array}{l}\text { Namibia } \\
(\mathrm{N}=303)\end{array}$ & $\begin{array}{l}\text { Zambia } \\
(\mathrm{N}=945)\end{array}$ \\
\hline \multicolumn{5}{|l|}{ Women's empowerment } \\
\hline Has any say in all four household decisionst & $1.33(0.84-2.10)$ & $1.28(0.62-2.68)$ & $2.32(1.01-5.34)^{*}$ & $0.85(0.58-1.25)$ \\
\hline None of five reasons for wife beating are justified $\neq$ & $1.03(0.53-1.99)$ & $0.41(0.21-0.82)^{*}$ & $1.08(0.46-2.51)$ & $1.14(0.81-1.60)$ \\
\hline All three reasons for refusing sex are justified $§$ & $1.30(0.84-2.02)$ & $1.27(0.58-2.76)$ & $1.34(0.66-2.72)$ & $1.43(1.01-2.02)^{*}$ \\
\hline \multicolumn{5}{|l|}{ Husband's influence } \\
\hline \multicolumn{5}{|l|}{ Husband's ideal no. of children } \\
\hline Agrees with wife †† & (ref) & (ref) & (ref) & (ref) \\
\hline Higher than wife's & $2.94(1.19-7.28)^{*}$ & $11.88(2.20-64.09)^{* *}$ & $2.98(1.20-7.40)^{*}$ & $2.22(1.28-3.87)^{* *}$ \\
\hline Lower than wife's & $1.06(0.32-3.53)$ & $2.07(0.28-15.14)$ & $0.40(0.13-1.21)$ & $0.60(0.33-1.10)$ \\
\hline Gave nonnumeric response, but wife did not & $3.17(1.10-9.14)^{*}$ & $9.07(1.57-52.49)^{*}$ & $2.24(0.30-16.66)$ & $1.44(0.54-3.84)$ \\
\hline \multicolumn{5}{|l|}{ Social and demographic } \\
\hline Current age & $1.09(1.04-1.14)^{* * *}$ & $0.98(0.93-1.03)$ & $1.00(0.91-1.09)$ & $1.06(1.02-1.10)^{* *}$ \\
\hline \multicolumn{5}{|l|}{ Residence } \\
\hline Urban & $1.56(0.62-3.96)$ & $1.34(0.60-3.00)$ & $0.64(0.29-1.41)$ & $1.07(0.64-1.78)$ \\
\hline Rural & (ref) & (ref) & (ref) & (ref) \\
\hline \multicolumn{5}{|l|}{ Household wealth index } \\
\hline Poorest & (ref) & (ref) & (ref) & (ref) \\
\hline Poor & $0.63(0.31-1.25)$ & $1.05(0.53-2.09)$ & $2.96(0.89-9.84)$ & $0.97(0.56-1.67)$ \\
\hline Middle & $0.86(0.47-1.59)$ & $0.80(0.36-1.78)$ & $2.31(0.83-6.44)$ & $1.17(0.70-1.95)$ \\
\hline Rich & $0.61(0.30-1.23)$ & $0.88(0.38-2.04)$ & $1.24(0.41-3.79)$ & $0.83(0.44-1.56)$ \\
\hline Richest & $0.59(0.19-1.87)$ & $0.51(0.15-1.68)$ & $1.76(0.43-7.21)$ & $1.40(0.63-3.13)$ \\
\hline \multicolumn{5}{|l|}{ Education } \\
\hline None (ref) & (ref) & (ref) & (ref) & (ref) \\
\hline Primary & $1.05(0.36-3.08)$ & $1.50(0.62-3.60)$ & $0.71(0.25-2.00)$ & $1.19(0.73-1.94)$ \\
\hline zsecondary & $1.05(0.44-2.48)$ & $2.87(1.01-8.13)^{*}$ & $0.64(0.22-1.82)$ & $0.95(0.49-1.85)$ \\
\hline Polygamous union & $0.62(0.38-1.01)$ & $1.31(0.76-2.24)$ & $0.98(0.38-2.56)$ & $0.89(0.59-1.35)$ \\
\hline
\end{tabular}

sexual rights may not actually have the power to determine their own sexual and reproductive trajectories. Given the current emphasis on HIV prevention in Sub-Saharan Africa, messaging on a wife's ability to refuse sex has become common, but women may still not be able to refuse.

Attitudes toward wife beating were also inconsistently associated with the study outcomes. Among the eight models, only three demonstrated an association in the expected direction. Research on this measure has found that respondents often have trouble understanding the different hypothetical situations and may provide socially desirable responses. ${ }^{62}$ Nevertheless, of the three empowerment measures used in this study, attitudes toward wife beating produced the results most consistent with our hypotheses.

By examining the effects of empowerment in four countries with diverse socioeconomic characteristics, our study provides a useful picture of women's empowerment in a variety of contexts in Sub-Saharan Africa. Our results should be interpreted in light of each country's national context. In countries where fertility is more closely linked to women's status, as in Mali, it is possible that women who have many children (and may believe having many children is ideal) are accorded more rights and power in the household. ${ }^{63}$ In such countries, society assigns significant social status to women who bear children, whereas childlessness usually carries negative social consequences. ${ }^{30-32}$ Zambia and Namibia, where empowered women had more children than they considered ideal, are in a process of transition, with fertility declining steadily in both countries, albeit slowly in Zambia. ${ }^{55,56}$

By comparing actual fertility and ideal fertility, we used a proxy measure for unwanted fertility. This measure may be more reliable than conventional measures of unintended pregnancy, which require women to say whether a particular child was wanted. Although women's ideal number of children may change over the course of their reproductive lives, the measure can provide a snapshot of their satisfaction at the end of childbearing. In the countries in this study, $12-28 \%$ of women aged 35 or older reported having more children than their ideal. Substantial reductions in the high total fertility rate could occur if women could avoid undesired fertility and have only the number of children they consider ideal.

Women's empowerment as measured by household decision making was associated with women's ideal number of children in only one of the four countries in this study. In contrast, previous studies-mostly in Asia, but using similar empowerment measures-have found that higher autonomy is associated with lower fertility. ${ }^{12,37,38}$ This discrepancy may be a result of the differences in cultural con- 
text between Africa and Asia. Household decision making may not be as relevant an indicator for empowerment in the Sub-Saharan African context; gender-role attitudes may be better at capturing variation in empowerment among these populations. Thus, more intensive efforts are needed to develop validated measures of women's empowerment. This process begins with qualitative research that explores what empowerment means in this region, to develop more contextually appropriate indicators of women's empowerment. It involves the development of scale items that capture women's empowerment in a variety of contexts, testing those items and conducting psychometric analyses to ensure reliability and validity-especially construct validity. This need for appropriate measures is becoming more urgent as countries around the world strive for gender equality and women's empowerment as part of achieving the Millennium Development Goals.

Given the lack of associations found between individual women's empowerment and fertility, future research should explore the community effects of gender context in Sub-Saharan Africa to determine whether it has greater explanatory power in its association with fertility outcomes. To date, only a handful of studies have examined community effects of women's empowerment and fertility outcomes, ${ }^{37,64-66}$ leaving significant gaps in our knowledge.

Researchers have posited that the well-established effect of women's education on fertility may be explained by education's effect of empowering women. ${ }^{13,40}$ Our study suggests, however, that women's empowerment does not sufficiently account for the association of education with fertility. In all countries except Namibia, higher education was associated with a smaller ideal number of children, even after controlling for women's empowerment. Thus, education may affect women's fertility in other ways besides increasing autonomy and having equitable genderrole attitudes. It may be that other dimensions of empowerment are affected by education, or that education itself has a direct effect. The cross-sectional nature of our data does not allow us to examine the direction of this effect, and in future studies, it will be important to separate and examine the individual contributions of each of these factors.

Our results demonstrate that husbands' ideal number of children is strongly associated with women's preferences, as well as with women's ability to achieve their reproductive preferences. As expected, having a husband who has a smaller ideal number of children was associated with having a smaller ideal number of children, independent of a woman's level of empowerment. There are two possible explanations for this finding. First, women may couple with like-minded men, and thus their ideal family sizes agree. Second, after marriage, spouses may conform to each other's ideals. Our analysis of achievement of ideal number of children found that women whose husbands wanted more children had decreased odds of realizing their own reproductive goals. These measures, which focus on autonomy and broader gender role beliefs, may not be specifically relevant to reproductive health outcomes. A measure that captures personal empowerment specifically in family planning and fertility domains may be more useful in explaining fertility-related outcomes. These findings also have the practical implication that addressing men's needs for information and resources for spacing and limiting their children is a useful investment for policies and programs.

Women's empowerment within polygamous unions requires special attention. In Mali and Zambia, women in polygamous unions had a smaller ideal number of children, which could suggest that these women take into account the total number of children in the household when deciding the ideal number of children for themselves; this explanation is consistent with the literature on polygamy and fertility ${ }^{67}$ This study was not designed to examine women's empowerment in polygamous unions or the role of the husband's influence in different types of family structures, but these interactions should be further considered in future studies and when developing measures of women's empowerment.

\section{Limitations and Strengths}

One limitation of this study is the presence and treatment of nonnumeric responses to the DHS question on ideal number of children. Thinking about one's ideal number of children is a complex process, and for many, it can be difficult to provide a numeric response. We explored this subsample and determined that they were similar to the rest of the sample on most of the women's empowerment indicators. Thus, we were comfortable with setting nonnumeric responses to the mean ideal number of children, with the rationale that this group is likely to have a variation in preferences similar to the rest of the sample.

Additional factors at the individual, family, community and national levels that were beyond the scope of this analysis may be associated with a woman's ability to achieve her desired family size. For example, at the individual level, misinformation about fecundity and ambivalence about getting pregnant would likely influence a woman's desired fertility and her fertility-related behavior. At the societal level, abortion remains highly restricted in these countries, which places additional constraints on a woman's ability to avoid having more children than she wants. Future research should examine these factors.

One of the study's strengths is that it examined men's influence on women's wanted and actual fertility-an influence that has rarely been included in previous studies. We used men's actual reports of their own ideal family size in our models, which required the use of a subsample of matched couples, thereby compromising our sample size. Even so, we believe that examining husbands' influence greatly adds to the richness of our findings.

\section{Conclusion}

As countries around the world work to promote gender equality and empower women as part of achieving the Millennium Development Goals, stronger and more robust 
methodological research is needed to identify instruments that measure women's empowerment with greater specificity and sensitivity. The enormous challenge we face is that these instruments must be sufficiently responsive to the unique gender contexts of specific communities, yet also applicable in a variety of contexts for cross-national comparisons. Equipped with such tools, we can appropriately target interventions to increase women's empowerment and assess the impact of these interventions on important measures of reproductive health.

\section{REFERENCES}

1. Lee-Rife SM, Women's empowerment and reproductive experiences over the lifecourse, Social Science \& Medicine, 2010, 71(3):634642.

2. Malhotra A, Schuler SR and Boender C, Measuring Women's Empowerment as a Variable in International Development, Washington, DC: World Bank, June 28, 2002, <http://hdr.undp.org/docs/ network/hdr_net/GDI_GEM_Measuring_Womens_Empowerment. pdf $>$, accessed May 15, 2012

3. Kabeer N, Reflections on the measurement of women's empowerment. Discussing Women's Empowerment-Theory and Practice, Sida Studies, Stockholm: Novum Grafiska AB, 2001, No.3.

4. Haile A and Enqueselassie F, Influence of women's autonomy on couple's contraception use in Jimma town, Ethiopia, Ethiopian Journal of Health Development, 2006, 20(3):145-151.

5. Hindin MJ and Adair LS, Who's at risk? Factors associated with intimate partner violence in the Philippines, Social Science $\&$ Medicine, 2002, 55(8):1385-1399.

6. Al Riyami A, Afifi M and Mabry RM, Women's autonomy, education and employment in Oman and their influence on contraceptive use, Reproductive Health Matters, 2004, 12(23):144-154.

7. Govindasamy P and Malhotra A, Women's position and family planning in Egypt, Studies in Family Planning, 1996, 27(6):328-340.

8. Blanc AK and Wolff B, Gender and decision-making over condom use in two districts in Uganda, African Journal of Reproductive Health, 2001, 5(3):15-28.

9. Kishor S and Gupta K, Women's empowerment in India and its states: evidence from the NFHS, Economic and Political Weekly, 2004, 39(7):694-712.

10. Gage AJ, Women's socioeconomic position and contraceptive behavior in Togo, Studies in Family Planning, 1995, 26(5):264-277.

11. Santillán D et al., Developing indicators to assess women's empowerment in Vietnam, Development in Practice, 2004, 14(4):534549.

12. Dyson M and Moore M, On kinship structure, female autonomy, and demographic behavior in India, Population and Development Review, 1983, 9(1):35-60.

13. Mason KO, The impact of women's social position on fertility in developing countries, Sociological Forum, 1987, 2(4):718-745.

14. Kishor S and Subaiya L, Understanding women's empowerment: a comparative analysis of demographic and health surveys (DHS) data, DHS Comparative Reports, Calverton, MD, USA: Macro International, 2008, No. 20

15. Ethiopian Society of Population Studies, Gender Inequality and Women's Empowerment, Addis Ababa: United Nations Population Fund (UNFPA), 2008, <http://ethiopia.unfpa.org/drive/Gender. pdf>, accessed May 15, 2012

16. Dhaher EA et al., Attitudes toward wife beating among Palestinian women of reproductive age from three cities in West Bank, Journal of Interpersonal Violence, 2010, 25(3):518-537.

17. Linos N, Khawaja M and Al-Nsour M, Women's autonomy and support for wife beating: findings from a population-based survey in Jordan, Violence and Victims, 2010, 25(3):409-419.
18. Hindin MJ, Understanding women's attitudes towards wife beating in Zimbabwe, Bulletin of the World Health Organization, 2003, 81(7):501-508.

19. Adhikari R and Sawangdee Y, Influence of women's autonomy on infant mortality in Nepal, Reproductive Health, 2011, 8(7):1-8.

20. Afifi M, Women's empowerment and the intention to continue the practice of female genital cutting in Egypt, Archives of Iranian Medicine, 2009, 12(2):154-160.

21. Shroff M et al., Maternal autonomy is inversely related to child stunting in Andhra Pradesh, India, Maternal and Child Nutrition, 2009, 5(1):64-74

22. Lawoko S, Factors associated with attitudes toward intimate partner violence: a study of women in Zambia, Violence and Victims, 2006, 21(5):645-656

23. Schatz E and Williams J, Understanding women's status, empowerment and autonomy in sub-Saharan Africa: the need to contextualize and validate DHS gender analyses with supplemental qualitative data, paper presented at the annual meeting of the Population Association of America, Washington, DC, Mar. 31-Apr. 2, 2011.

24. Stephenson R, Bartel D and Rubardt M, Constructs of power and equity and their association with contraceptive use among men and women in rural Ethiopia and Kenya, Global Public Health, 2012 (forthcoming).

25. Schuler SR, Islam F and Rottach E, Women's empowerment revisited: a case study from Bangladesh, Development in Practice, 2010, 20(7):840-854

26. Dodoo FNA, Marriage type and reproductive decisions: a comparative study in sub-Saharan Africa, Journal of Marriage and the Family, 1998, 60(1):232-242.

27. Bove R and Valeggia C, Polygyny and women's health in subSaharan Africa, Social Science \& Medicine, 2009, 68(1):21-29.

28. Mbizvo MT and Bassett MT, Reproductive health and AIDS prevention in sub-Saharan Africa: the case for increased male participation, Health Policy and Planning, 1996, 11(1):84-92.

29. Westoff $C$ and Bankole A, Reproductive preferences in developing countries at the turn of the century, DHS Comparative Reports, Calverton, MD, USA: ORC Macro, 2002, No. 2.

30. Harrison A and Montgomery E, Life histories, reproductive histories: rural South African women's narratives of fertility, reproductive health and illness, Journal of Southern African Studies, 2001, 27(2):311-328

31. Cooper D et al., "Life is still going on": reproductive intentions among HIV-positive women and men in South Africa, Social Science E Medicine, 2007, 65(2):274-283.

32. Donkor ES and Sandall J, The impact of perceived stigma and mediating social factors on infertility-related stress among women seeking infertility treatment in Southern Ghana, Social Science E Medicine, 2007, 65(8):1683-1694

33. Schuler SR, Hashemi SM and Riley AP, The influence of women's changing roles and status in Bangladesh's fertility transition: evidence from a study of credit programs and contraceptive use, World Development, 1997, 25(4):563-575.

34. Morgan SP and Niraula BB, Gender inequality and fertility in two Nepali villages, Population and Development Review, 1995, 21(3):541561

35. Gwako EL, Conjugal power in rural Kenya families: its influence on women's decisions about family size and family planning practices, Sex Roles, 1997, 36(3-4):127-147.

36. Woldemicael G, Women's autonomy and reproductive preferences in Eritrea, Journal of Biosocial Science, 2009, 41(2):161-181.

37. Balk D, Individual and community aspects of women's status and fertility in rural Bangladesh, Population Studies, 1994, 48(1):21-45.

38. Hindin MJ, Women's autonomy, women's status and fertilityrelated behavior in Zimbabwe, Population Research and Policy Review, 
$2000,19(3): 255-282$

39. Upadhyay UD and Hindin MJ, Do higher status and more autonomous women have longer birth intervals? Results from Cebu, Philippines, Social Science E Medicine, 2005, 60(11):2641-2655.

40. Jejeebhoy SJ, Women's Education, Autonomy, and Reproductive Behaviour: Experience from Developing Countries, Oxford: Clarendon Press, 1995.

41. Hogan DP, Berhanu B and Hailemariam A, Household organization, women's autonomy, and contraceptive behavior in southern Ethiopia, Studies in Family Planning, 1999, 30(4):302-314.

42. Shapiro D, Fertility Transition in sub-Saharan Africa: falling and stalling, African Population Studies, 2008, 22(2):3-23.

43. United Nations Population Division, World Population Prospects: The 2008 Revision, New York: Population Division of the Department of Economic and Social Affairs of the United Nations Secretariat, <http://www.un.org/esa/population/publications/ wpp2008/wpp2008_highlights.pdf>, accessed May 15, 2012

44. Sedgh $G$ et al., Women with an unmet need for contraception in developing countries and their reasons for not using a method, Occasional Report, New York: Guttmacher Institute, 2007, No. 37.

45. Ezeh AC, The influence of spouses over each other's contraceptive attitudes in Ghana, Studies in Family Planning, 1993, 24(3):163174.

46. Speizer I, Men, marriage, and ideal family size in francophone Africa, Journal of Comparative Family Studies, 1999, 30(1):17-34.

47. Bankole A and Singh S, Couples' fertility and contraceptive decision-making in developing countries: hearing the man's voice, International Family Planning Perspectives, 1998, 24(1):15-24.

48. Gebreselassie T, Spousal agreement on reproductive preferences in Sub-Saharan Africa, DHS Analytical Studies, Calverton, MD, USA Macro International, 2008, <http://www.measuredhs.com/pubs/ pdf/AS10/AS10.pdf>, accessed May 15, 2012

49. Short SE and Kiros G-E, Husbands, wives, sons, and daughters: fertility preferences and the demand for contraception in Ethiopia, Population Research and Policy Review, 2002, 21(5):377-402.

50. DeRose LF, Dodoo FNA and Patil V, Fertility desires and perceptions of power in reproductive conflict in Ghana, Gender \& Society, 2002, 16(1):53-73.

51. UN Women, Progress of the World's Women: In Pursuit of Justice, New York: UN Women, 2011, <http://progress.unwomen.org/pdfs/ EN-Report-Progress.pdf>, accessed May 15, 2012

52. United Nations Population Division, World Population Prospects: The 2010 Revision, New York: Population Division of the Department of Economic and Social Affairs of the United Nations Secretariat, 2011.

53. Ministry of Health Mali, National Directorate of Statistics Mali and Macro International, Mali Demographic and Health Survey, 2006, Calverton, MD, USA: Macro International, 2007.

54. National Statistics Directorate (DNS) Guinea and Macro International, Guinea Demographic and Health Survey, 2005, Calverton, MD, USA: DNS and Macro International, 2006.

55. Central Statistical Office (CSO) Zambia et al., Zambia Demographic and Health Survey, 2007, Calverton, MD, USA: CSO and Macro International, 2009.

56. Ministry of Health and Social Services (MoHSS) Namibia and Macro International, Namibia Demographic and Health Survey, 200607, Windhoek, Namibia: MoHSS; and Calverton, MD, USA: Macro International, 2008.

57. UNAIDS and World Health Organization (WHO), 2009 AIDS Epidemic Update, Geneva: UNAIDS/WHO, 2009.

58. Olaleye DO, Ideal family size: a comparative study of numerical and non-numerical fertility desires of women in two sub-Saharan African countries, DHS Working Papers, Calverton, MD, USA: Macro International, 1993, No. 7, <http://www.measuredhs.com/ publications/publication-wp7-working-papers.cfm>, accessed May 15,2012
59. Riley AP, Hermalin AI and Rosero-Bixby L, A new look at the determinants of nonnumeric response to desired family size: the case of Costa Rica, Demography, 1993, 30(2):159-174.

60. Hindin MJ, Women's input into household decisions and their nutritional status in three resource-constrained settings, Public Health Nutrition, 2006, 9(4):485-493.

61. Mullany BC, Hindin MJ and Becker S, Can women's autonomy impede male involvement in pregnancy health in Katmandu, Nepal? Social Science E Medicine, 2005, 61(9):1993-2006.

62. Schuler SR, Methods for assessing attitudes toward intimate partner violence in rural Bangladesh, paper presented at the annua meeting of the Population Association of America, Dallas, TX, USA April 15-17, 2010

63. Dyer SJ, The value of children in African countries: insights from studies on infertility, Journal of Psychosomatic Obstetrics and Gynaecology, 2007, 28(2):69-77.

64. Bates LM, Maselko J and Schuler SR, Women's education and the timing of marriage and childbearing in the next generation: evidence from rural Bangladesh, Studies in Family Planning, 2007, 38(2):101-112

65. Benefo KD, The determinants of the duration of postpartum sexual abstinence in West Africa: a multilevel analysis, Demography, 1995, 32(2):139-157.

66. DeRose LF and Ezeh AC, Decision-making patterns and contraceptive use: evidence from Uganda, Population Research and Policy Review, 2010, 29(3):423-439.

67. Pebley A, Mbugua W and Goldman N, Polygyny and fertility in Sub-Saharan Africa, Fertility Determinants Research Notes, 1988, (21):6-10.

\section{RESUMEN}

Contexto: Las Encuestas Demográficas y de Salud (EDS) recopilan datos sobre el empoderamiento de la mujer pero se sabe poco sobre lo que estas medidas representan en los países de África subsahariana. Es importante comprender si el empoderamiento de la mujer está asociado con el número ideal de hijos y con su capacidad de limitar su fecundidad a ese número ideal en el contexto africano subsahariano.

Métodos: El análisis usó los datos de encuestas EDS de cuatro países africanos subsaharianos: Guinea, Malí, Namibia y Zambia. El empoderamiento de la mujer se midió a través de su participación en la toma de decisiones familiares, de sus actitudes respecto a golpear a la esposa y de sus actitudes respecto al rechazar las relaciones sexuales con el esposo. Se utilizó regresión lineal multivariada para modelar el número ideal de hijos de la mujer, y regresión logística multivariada para modelar las probabilidades de tener más hijos que el número ideal.

Resultados: En Guinea y Zambia, la actitudes negativas respecto a golpear a la esposa estuvieron asociadas con el hecho de tener un menor número ideal de hijos (coeficientes beta, -0.5 y -0.3 , respectivamente). Un mayor poder de toma de decisiones familiares estuvo asociado con un menor número ideal de hijos solamente en Guinea (coeficiente beta, -0.3). Además, la toma de decisiones familiares en Namibia y las actitudes positivas respecto al rechazo de las relaciones sexuales en Zambia se asociaron con mayores probabilidades de tener más hijos que el número ideal (razones de momios, 2.3 y 1.4, respectivamente); en Malí, las actitudes negativas respecto a golpear a la esposa estuvieron asociados con probabilidades reducidas de tener más hijos que el número ideal (0.4). 
Conclusiones: En estos países africanos subsaharianos, el empoderamiento de la mujer-evaluado a través de las medidas que actualmente están disponibles-no está asociado consistentemente con un deseo por tener familias más pequeñas o con la capacidad de lograr la fecundidad deseada. Se necesita más investigación para determinar qué medidas son más aplicables en estos contextos.

\section{RÉSUMÉ}

Contexte: Le programme d'Enquêtes démographiques et de santé (EDS) collecte des données sur l'autonomisation des femmes, mais on en sait peu sur l'utilité de ces mesures dans les pays d'Afrique subsaharienne. Il est important de comprendre si l'autonomisation des fermmes est associée à leur nombre idéal d'enfants et à leur capacité de limiter leur fécondité à ce nombre idéal dans le contexte subsaharien.

Méthodes: L'analyse repose sur les données de couple des enquêtes EDS de quatre pays d'Afrique subsaharienne: la Guinée, le Mali, la Namibie et la Zambie. L'autonomisation des femmes est mesurée en fonction de la participation aux décisions du ménage, des attitudes à l'égard du droit pour un homme de battre sa femme et des attitudes à l'égard du refus de rapports sexuels avec le mari. Le nombre d'enfants idéal des fermmes est modélisé par régression linéaire multivariée et leur risque d'avoir plus d'enfants que ce nombre idéal, par régression logistique multivariée.

Résultats: En Guinée et en Zambie, les attitudes négatives à l'égard du droit de battre sa femme sont associées à un nombre idéal d'enfants plus faible (coefficients bêta, $-0,5$ et $-0,3$, respectivement). Une plus grande participation aux décisions $d u$ ménage n'est associée à un moindre nombre d'enfants idéal qu'en Guinée (coefficient bêta, -0,3). De plus, la participation aux décisions du ménage en Namibie et les attitudes positives à l'égard du refus des rapports sexuels en Zambie sont associées à une probabilité élevée d'avoir plus d'enfants que le nombre désiré (OR, 2,3 et 1,4, respectivement); les attitudes négatives à l'égard du droit de battre sa femme au Mali sont associées à une probabilité moindre de ce résultat $(0,4)$.

Conclusions: L'autonomisation des femmes - telle qu'évaluée selon les mesures actuellement disponibles - n'est pas uniformément associée à un désir de famille moins nombreuse ou à la capacité d'atteindre la fécondité désirée dans ces pays d'Afrique subsaharienne. La recherche doit être approfondie pour déterminer les mesures les plus pertinentes dans ces contextes.

\section{Acknowledgments}

The authors thank Sunita Kishor of ICF Macro and Simona Bignami of the University of Montreal for their guidance and insightful comments; Bryant Robey for his constructive comments and editorial expertise; and Karen Hardee of Population Action International for her comments on an earlier draft presented at the 2010 annual meeting of the Population Association of America. This study was supported by a fellowship from the United States Agency for International Development (USAID) through the MEASURE DHS project at ICF Macro.

Author contact: upadhyayu@obgyn.ucsf.edu 